\title{
Cluster Analysis Referring to Rural Enterprises of Sugarcane Local Productive Arrangement (LPA) in Quirinópolis, Brazil
}

\author{
Jean Marc Nacife ${ }^{1}$, Frederico A. Loureiro Soares ${ }^{1}$ \& Gustavo Castoldi ${ }^{1}$ \\ ${ }^{1}$ Department of Technical and Technological Education, Goiano Federal Institute (IF Goiano), Rio Verde, Brazil \\ Correspondence: Jean Marc Nacife, Department of Technical and Technological Education, Goiano Federal Institute, \\ Rio Verde, Brazil. Tel: 55-649-9963-4589.
}

Received: July 29, 2019

doi:10.5430/ijba.v10n5p1
Accepted: August 17, 2019

Online Published: August 21, 2019

URL: https://doi.org/10.5430/ijba.v10n5p1

\begin{abstract}
In Brazil in recent decades, the the dynamics of land use widened the agricultural frontier for sugarcane cultivation by modifying and replacing intensively traditional and pasture crops. It is proposed to examine the aggregating characteristics of rural enterprises that are part of the sugarcane agribusiness productive arrangement, evaluating their profiles, providing a more effective understanding of their socioeconomic sustainability. The quantitative approach was adopted applying statistical tests for variable selection and multivariate statistical techniques (cluster analysis) to evaluate rural enterprises. The results indicated two clusters with peculiar profiles, and the average distance between farm and agribusiness $( \pm 22 \mathrm{~km})$ and succession capacity $( \pm 2.5$ points $)$ of both are similar. The other variables were discrepant $(\mathrm{P}<0.05)$, in cluster 1 the very negative rural exodus $(-48 \%)$ and in cluster 2 positive $(23 \%)$. Operating costs in relation to compensation for Cluster 1 was $61 \%$, much higher than cluster 2 with $6 \%$ on average. It was concluded that through cluster analysis that the contract variables and the size of the establishment are the most significant factors directly influencing the rural exodus and production costs. These observations contribute to the creation of sectorial policies for the use of land and regional economic development, as such imply in a theoretical consolidation of precepts on the sugarcane expansion, as such also imply, under the perspective of the rural practice, in elements for the improvement in planning the agricultural enterprise.
\end{abstract}

Keywords: agricultural economy, rural development, socioeconomic indicators, sugarcane agribusiness

\section{Introduction}

In Brazil over the past two decades, the agricultural frontier for sugarcane cultivation has been widened, changing the dynamics of land use by including new areas resulting from the replacement of traditional crops and/or pastures, mainly due to the expansion of biofuel production (Gilio, Moraes, 2016). Studies indicate that pasture is more likely to be exchanged for sugarcane than soybeans, and most of the sugarcane cultivation area was not produced over native Cerrado vegetation (Spera et al., 2017; Nacife et al., 2019). The expansion of sugarcane culture, despite having a positive impact on the economic in the implanted region (Nacife et al., 2019), has difficulty to insert in places where the actors and the infrastructure are well organized for other activities, making farmers less likely to sell, rent or convert pasture or soybeans to sugarcane (Spera et al., 2017).

Historically, high levels of concentration of capital and of rural property characterizes Brazil, and with the expansion of sugarcane culture, through land lease agreements between agricultural enterprises and the sugar-alcohol agroindustries; it has been perceived miscellaneous impacts on owners to mainly small loans (Petrini et al., 2017). Another issue that mainly affects small farms is the representativeness to political channels and insufficient power to participate in political management discourses to provide ways of influencing public policies that could safeguard those farms (Guanziroli et al., 2013).

In the Midwest region, Goiás has been receiving in the last years the largest investments of the sugar-energy sector and increased its participation in the national and international market very significantly, causing a strong impact on the economy, land use and social issues that it has demanded. Traditional agricultural production has been shifted to other regions and even restricted due to this phenomenon (Trindade, 2015; Petrini et al., 2017). Specifically in the state of Goiás, production jumped from 200,048 tons in 2005 to 69,726,355 tons of sugarcane in 2016, making this state the second largest national producer, surpassed only by São Paulo with 354,353,922 tons (IBGE, 2018a). 
Quirinópolis has a singularity that gives it national prominence, as it occupies the first place in the ranking of sugarcane producing cities in Goiás and the second place in Brazil with the production of 7.142.253.25 tons of sugarcane (IBGE, 2018a). The research was originally concentrated directly with the sugarcane-producing agricultural enterprises, with a locus geographically restricted to Quirinópolis, located in the southwest of Goiás, which is conceptually configured as a LPA. The conception of LPA for sugarcane in Quirinópolis, Goiás, comes from the understanding of the dynamics of the groups of actors and the powerlessness of the role they play in the local economy, provoked around innovation and knowledge creation (De Sordi and Meireles, 2012), but also from the theory of regional development, which brings the understanding that Local Productive Arrangements are formed by a set of economic activities that are linked to production, mutual influence, cooperation and learning, and that can be developed in socioeconomic and political territorial agglomerations. (Ribeiro et al., 2013; Justen and Paes-de-Souza, 2017) Such facts are verifiable in the city, besides being characterized by the easy access to the productive inputs such as: sugarcane, specialized labor, the geographic proximity of the political, economic and social agents, as well as of enterprises and other organizations allow the development of economies per cluster (De Sordi and Meireles, 2012; Justen and Paes-de-Souza, 2017).

Despite its economic relevance, studies of the sugarcane production system have lacked the most compelling evidence regarding social impacts. Regional development from sugarcane can negatively influence social vulnerability levels, also influencing the generation of social change processes (Ribeiro, 2013). The government has acted through regulatory frameworks, aiming to reduce the social and environmental impacts from the sugarcane production system, proposing zoning laws, environmental regulations and fostering voluntary workers rights agreements (Duarte et al., 2013). Even with the agricultural expansion, the rural exodus in the last decades has been increasing (IBGE, 2018a), however in regions where the sugarcane production system the number of families in the rural producing area has increased. (Maia et al., 2016) Clearly, the vast majority of studies address issues of economic and environmental sustainability, but social issues still need further study. There are several scientific studies that suggest benefits for the population of regions of expansion of the sugarcane industry in Brazil, citing mainly, the generation of jobs and income (Mangoyana et al., 2013; Ribeiro, 2013).

Plausible as a hypothesis, consider that the factors type of contract with agribusiness and territorial extension of farms influence the socioeconomic variables in sugarcane agribusiness. However, it is not explained at all, it is observed that rural enterprises, for example, may be less likely to lease or convert their production to sugarcane if they are in the midst of other rural soy or pasture establishments with supporting infrastructure to its well-structured and consolidated production (Gilio \& Moraes, 2016; Spera et al., 2017). The issue affects both sugarcane agribusiness (Asunción et al., 2016) and penetrating soybean and cattle across the Amazon and Cerrado (Garrett et al., 2013).

It is urgent to emphasize that knowledge about the specific dynamics of rural sector actors is still limited, which may imply difficulties or facilities for sustainable agricultural development depending on the focus. Socioeconomic insecurity and food conditions are also studied to contribute to more effective sectoral policies, effectively supporting food security policies and this bias can contribute to reducing vulnerability to food insecurity (Pervaiz et al., 2017). Thus, a systematic analysis of the current dynamics is required to obtain the necessary information on the possibilities of sustainable agricultural development to compose specific and effective policies (Escobal et al., 2015; Medina et al., 2015). In this sense, new alternative proposals for agricultural development have gained space in the political agendas, providing conditions for the implementation of projects aligned with this recent demand (Franks, 2014). The authors aim to examine, through Cluster Analysis, the aggregating characteristics of rural establishments hired by the sugarcane agroindustries, evaluating them and characterizing the profiles related to the socioeconomic factors that agglutinate them, providing a more effective understanding of agricultural enterprises.

\section{Method}

The field survey was conducted from June 2018 to February 2019 with the landowners. The studied rural establishments are located in the rural micro-regions of the city of Quirinópolis, geographically positioned by the coordinates: $18^{\circ} 26^{\prime} 52^{\prime \prime}$ south and $50^{\circ} 27^{\prime} 07^{\prime \prime}$ west, located in the southwest of Goiás and in the south mesoregion of the state (IBGE, 2018b).

\subsection{Sampling Procedures}

The research universe comprises the 67 existing sugarcane-producing agricultural establishments (IBGE, 2018a), parameter for the sample calculation. The sample adopted the $95 \%$ confidence level for data collection and analysis, with a sample error margin of 5\%, resulting in a sample of 58 agricultural establishments (Santos, 2016). The research is quantitative, with fieldwork adopting the survey method (Creswell, 2017). In the data collection, printed 
questionnaires were used for the interviews, contemplating the research variables (Table 1). The data collection questionnaire was divided into two distinct sections. In the first section, general data were collected on the profiles of landowners and agricultural establishments, and in the second, the conceptions about the research variables from the perspective of social and economical dimensions. In the first phase of the research, the questionnaire was pre-tested in the field to verify inadequacies, inconsistencies and errors in the questions, which allowed correcting ambiguities and other identified non-conformities. The application of the instrument covered 17 micro-regions that compose the local productive arrangement, as follows:

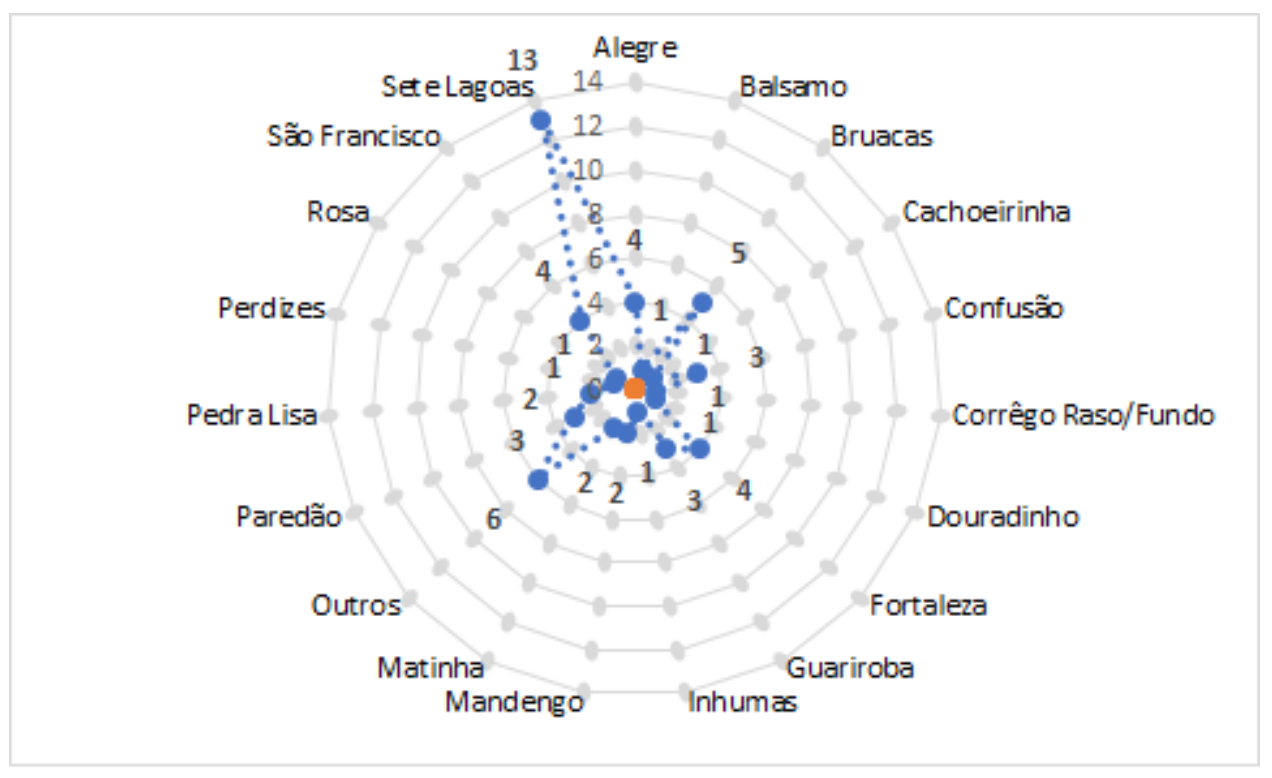

Figure 1. Frequency distribution for the sugarcane LPA microregion where the rural development is located

\subsection{Research Procedures}

The steps adopted to analyze the results were: (I) planning and elaboration of the questionnaires; (II) logistic study and data collection in agricultural establishments; (III) data tabulation; (IV) preliminary data analysis, sample adequacy assessment and statistical measures; (V) application of statistical normality tests (Kolmogorov-Smirnov), and Friedman's ANOVA; and (VI) Cluster Analysis concerning variables and data exploration through socioeconomic indicators. (Creswell, 2017) Data exploration and multivariate analysis were performed using the IBM SPSS Statistics 24.0.0.0® and Microsoft Office Excel $®$ applications.

\subsection{Measurements, Variables and Statistical Analysis}

Some statistical tests were necessary to reach the objectives, requiring tests of statistical significance of the variables. In Table 1, the variables tested and their identification are presented.

Table 1. List of variables considered for the validation tests and multivariate analysis

\begin{tabular}{|c|c|c|}
\hline Variable & Equation & Description \\
\hline Age & $\overline{\mathbf{x}}=\frac{\sum_{1=1}^{\mathbb{N}} \overline{\mathbf{X}_{1}}}{\mathbf{N}}$ & $\begin{array}{l}\text { represents the average age of the owners of the agricultural } \\
\text { establishments of the sugarcane activity. It contributes to the } \\
\text { understanding of the sociodemographic profile. }\end{array}$ \\
\hline $\begin{array}{l}\text { Agroindustry } \\
\text { Distance } \\
\text { (AgroDistance) }\end{array}$ & $\overline{\mathrm{X}}=\frac{\sum_{1=1}^{\mathrm{N}} \overline{\mathrm{X}_{1}}}{\mathbf{N}}$ & $\begin{array}{l}\text { agriculture and agroindustry (AgroDistance): which measures the } \\
\text { distance of the rural property and sugarcane agroindustry, using } \\
\text { the kilometer as measure. }\end{array}$ \\
\hline
\end{tabular}




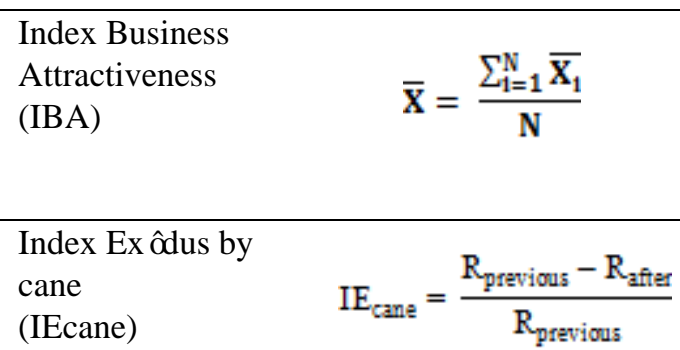

Index Succession

Capacity - ISC

expresses the main reasons for the change in the production system on earth. It consists of the following indicators: liquidity, income guarantee, profitability, production system, health condition, investment need and land appreciation. The Likert scale was used for scoring with values from 0 to 5 .

measures the number of people who emigrated from agricultural property after the change in the productive system, checking the location of the rural exodus. The index uses a linear rating scale, comprising negative and positive numbers (score).

measures the arithmetic average obtained in the evaluation of the variables: vocation, practical skills and technical training in relation to the successors in the management of agricultural establishments. It uses the Likert rating scale comprising numbers from 1 to 5 .

\begin{tabular}{|c|c|c|}
\hline Schooling & $\overline{\mathbf{X}}=\frac{\sum_{1=1}^{\mathrm{N}} \overline{\mathbf{X}_{1}}}{\mathbf{N}}$ & $\begin{array}{l}\text { represents the average of the levels of education levels of the } \\
\text { owners of the agricultural establishments of the sugarcane } \\
\text { activity. It contributes to the understanding of the } \\
\text { sociodemographic profile. }\end{array}$ \\
\hline $\begin{array}{l}\text { Size of } \\
\text { Establishment } \\
\text { (SizeEstablis) }\end{array}$ & $\overline{\mathrm{X}}=\frac{\sum_{\mathrm{i=1}}^{\mathrm{N}} \overline{\mathrm{X}_{1}}}{\mathbf{N}}$ & $\begin{array}{l}\text { measures the average size of rural properties. In this study were } \\
\text { identified establishments in the small, medium, large and small } \\
\text { classes, having the hectar (ha) as unit of measure. }\end{array}$ \\
\hline $\begin{array}{l}\text { Total Operating } \\
\text { Costs by cane } \\
\text { (TOCcane) }\end{array}$ & $\mathrm{TOC}_{\text {cane }}=\overline{\mathrm{Re}}$ & $\begin{array}{l}\text { calculated in relative percentage terms of remuneration. For the } \\
\text { purposes of this study, TOCcane was calculated in relation to the } \\
\text { t2 } 6 \text { - } 1 / 2018 \text { sugarcane crop in the establishments. }\end{array}$ \\
\hline $\begin{array}{l}\text { Type Contract } \\
\text { (TC) }\end{array}$ & $T \bar{C}=\frac{T C}{\mathrm{~N}}$ & $\begin{array}{l}\text { represents the reason for the impact of the modalities of the types } \\
\text { of contracts of agricultural establishments. It contributes to the } \\
\text { understanding of cost allocation. Contracts can be for leases or } \\
\text { supplies. }\end{array}$ \\
\hline
\end{tabular}

To deepen the profile design of rural establishments based on the variables, the clustering method using the TwoStep Cluster Analysis logarithm with Schwarz Bayesian clustering criterion (BIC) was applied. The equation represents the increase in the group internal error if groups' $\boldsymbol{p}$ and $\boldsymbol{q}$ are ungrouped, where $\boldsymbol{m}$ is the number of vectors in each group, $\boldsymbol{n}$ is the number of components of the database vectors and $\boldsymbol{i}$ is the index of the vector components.

$$
\Delta E=\frac{m_{p} m_{q}}{m_{p}+m_{q}} \cdot \sum_{i=1}^{i=n}\left(x_{i p}-\bar{x}_{i q)}{ }^{2}\right.
$$

\section{Results and Discussion}

Statistical normality and hypothesis tests were applied to the variables Type Contract, $\mathrm{TOC}_{\text {cane }}$, ISC, Size of Establishment, Agroindustry Distance, Schooling, Associate, IA, Remuneration, IEcane, Age and IBA, in order to prepare them for Cluster Analysis. Normality was measured, with satisfactory results, noting that two variables under test did not present a normal distribution and were eliminated due to their statistical significance (Age and IBA). The Kolmogorov-Smirnov test applied the variables validated under significance $(\mathrm{P}<0.05)$ and, additionally, Friedman's ANOVA was applied for hypothesis testing to verify rejection of the null hypothesis, with $95 \%$ reliability.

Table 2. Test for hypothesis and normal testing

\begin{tabular}{ccc}
\hline Description & $\begin{array}{c}\text { Test } \\
\text { Kolmogorov-Smirnov }\end{array}$ & $\begin{array}{c}\text { Analysis of Variance of } \\
\text { Friedman Factors }\end{array}$ \\
\hline Type Contract & $0,04^{*}$ & 0,00 \\
\hline TOC $_{\text {cane }}$ & 0,00 & 0,00 \\
\hline
\end{tabular}




\begin{tabular}{cll}
\hline ISC & 0,00 & 0,00 \\
\hline Size of Establishment & 0,00 & 0,00 \\
\hline Agroindustry Distance & 0,00 & 0,00 \\
\hline Schooling & 0,00 & 0,00 \\
\hline IEcane & 0,00 & 0,00 \\
\hline Age & 0,20 & 0,00 \\
\hline IBA & 0,20 & 0,00
\end{tabular}

Source: Primary data processed, 2018. Note. *Binominal test of a sample.

Quantitative variables with statistical significance were submitted to descriptive examination to express the general characteristics of rural enterprises of the local sugarcane productive arrangement. Descriptive statistics indicated that the measured standard deviation of the sample measured low values for AgroDistance (14.08), TOCcane (0.30), IEcane (1.15) and ISC (1.66), and high for the size variable of the rural establishment (1.429.46). Calculating standard deviation helps to interpret the level of homogeneity and dispersion of the results in Figure 2.

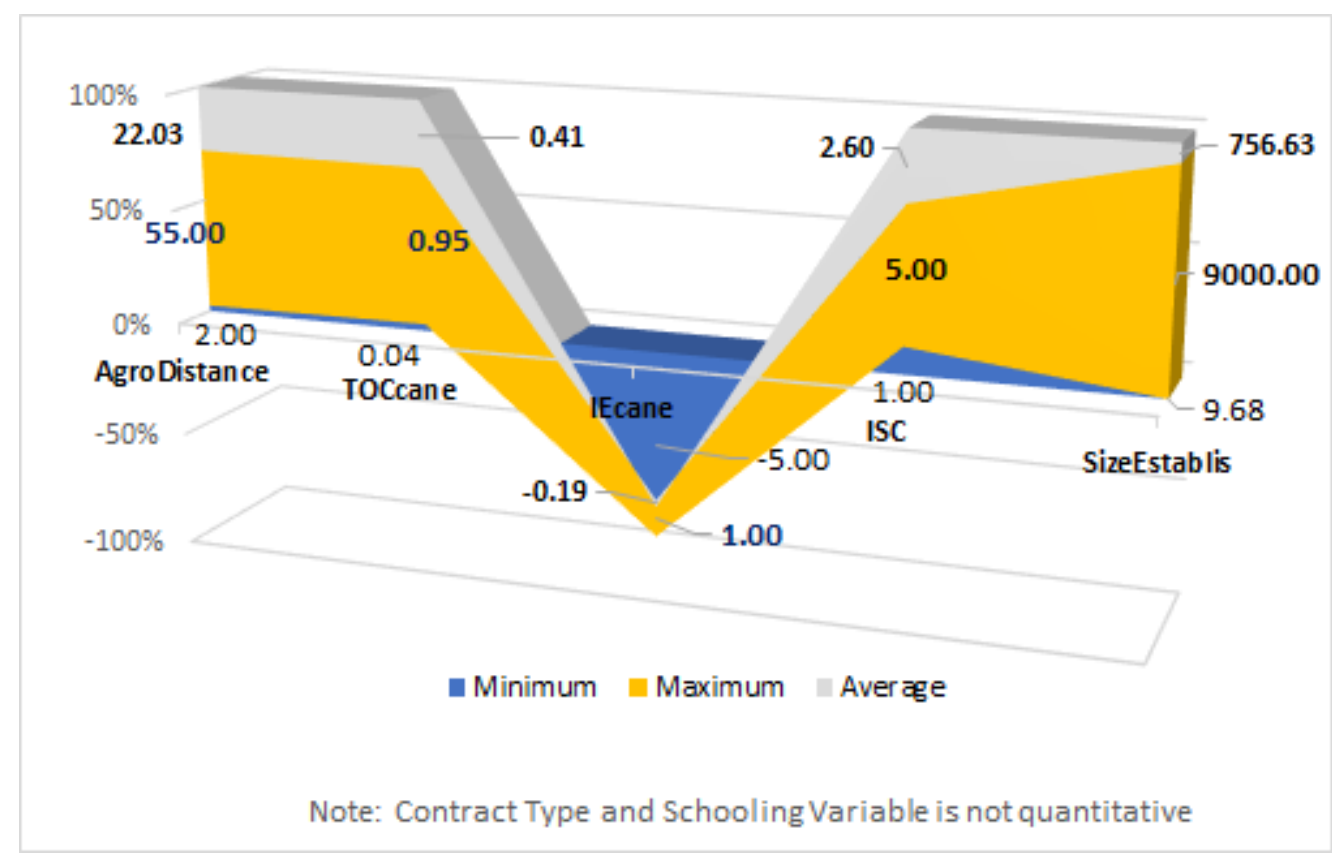

Figure 2. Descriptive statistics of the characteristics of rural enterprises

In terms of general characteristics in relation to the variables proposed in this study, it was found that the distance between rural enterprises and the sugarcane agribusiness is $22.03 \mathrm{~km}$, consolidating findings from previous studies that assert that the ideal transport logistics for this agribusiness is within $50 \mathrm{~km}$ (Gilio \& Moraes, 2016; Spera et al., 2017). Regarding operating costs, a very large amplitude is perceived, but its standard deviation is small, indicating homogeneity. This feature is explained by the fact that LPA is basically made up of two types of contracts between rural enterprise and agribusiness, in which it has the composite of similar costs (lessor and supplier), which indicates the near average condensation in the groupings by type of contract. The behavior of the rural exodus variable $(-0.19)$ in the LPA is opposite to the national dynamics verified (IBGE, 2018b). It is understood that the sample is mainly composed of sugarcane supply enterprises, which was found in an earlier study that this type of establishment requires labor in the field causing a negative effect on the exodus indicator (Nacife et al., 2019). The variable that measures the perception of the owners of rural enterprises regarding the qualification of their successors to take on agribusiness obtained an average score, which may infer that in relation to the proposed parameters (vocation, practical skill and technical training) there is no indication of a general condition to undertake the activities, but these data should be better examined for further consideration. The issue involving the territorial size of the farms can be 
inferred (Figure 2) that there is a wide explanatory variability of this variable.

After the preliminary statistical tests, the sugarcane productive system variables were submitted to Cluster Analysis, aiming at the segmentation of the profiles of the rural enterprises and the extraction of information about the research data. Cluster Analysis configured a dendogram with the variable groups from the data fit, modeling so that the most influential factors in each cluster were determined as a result of the combination of their characteristics and similarities. With the intention of verifying the relation between the agricultural establishments, cluster analysis through the TwoStep algorithm combined the input of 7 factors, obtaining a cohesion and separation silhouette of 0.5 and forming 2 clusters.

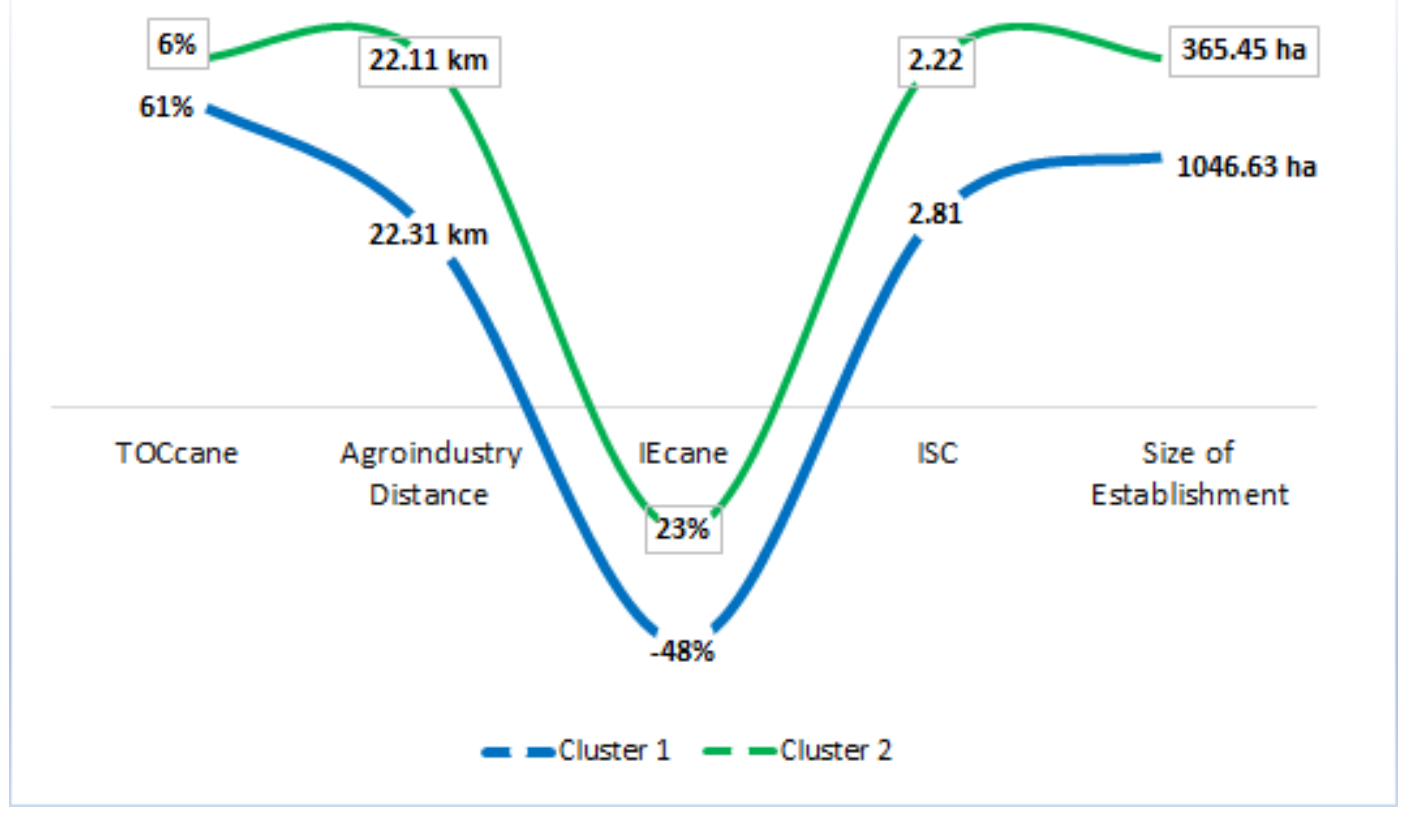

Figure 3. Agglomeration by profile of socioeconomic indicators of rural enterprises

Cluster 1 is comprised of predominantly sugarcane suppliers (97\%), so their average total operating cost in relation to total compensation $(61 \%)$ is higher than that of cluster $2(6 \%)$, in which predominate farms leases for sugarcane production activity, and because the owner does not perform the productive activity directly, its average total cost in relation to total compensation is low, as it refers only to administrative and tax costs generally. The average size of these rural farms in cluster 1 is $1,046.63$ hectares, approximately \pm 3 times larger than the average size of farms in cluster 2 (365.45 ha). Studies show that the gain in production scale is an important factor in the production and trading of commodities, and territorial extension is an important variable for hiring the rural establishments that integrate the sugarcane production system (Nagavarapu 2010; Gilio \& Moraes, 2016; Spera et al. 2017). Cluster analysis indicated that the largest farms are the furthest from the agro-industry, but the average distances between the two farms and the sugarcane processing industry are similar $( \pm 22 \mathrm{~km})$. Transport logistics is fundamental to the economic sustainability of the sugarcane business (Spera et al., 2017), since the farther distances imply losses in product quality. The most distant rural establishments in this study are $55 \mathrm{~km}$, confirming other correlated studies on this factor, which demonstrate that, for the economic sustainability of the sugarcane activity, it must have a distance of up to $\pm 50 \mathrm{~km}$ to avoid negatively impact on the economic outcome (Roviero, 2014; Egeskog et al., 2016; Spera et al., 2017).

Regarding the social factors studied, it was found that the farms that are part of cluster 1 had a very negative rural exodus index (-48\%), an unusual fact, since the Brazilian rural establishments have an inverse trend of this result (IBGE, 2008b). This result is due to the own productive activity developed by the sugarcane supplier farmer, which needs more labor force on the property and, consequently, more people start to live in the field, justifying the exodus indication in these properties to be negative, contrary to what was found in Brazilian farms in general (Nacife et al., 2019). The farms of cluster 2 followed the general trend of Brazilian rural establishments, obtaining a significant 
exodus indicator (23\%), which is explained by the reduction in the number of people living in the rural property after being handed over to the agro-industry. sugarcane production. The landowner and the rural workers with their families often leave the land because they no longer worked in that area, as the labor force that will be employed on the farm will be from the agribusiness (Nacife et al., 2019). The ISC is an indicator that measures the level of qualification of the successors of the studied farms, where the following values were obtained by the successors: cluster 1 was 2.81 and cluster 2 was 2.22 (rating scale between 1 and 5). The scores obtained in both clusters can be considered average, and reflecting that this indicator reports the variables vocation, practical skill and technical knowledge for rural activities, it is clear that successors are not yet able to take over the rural business. A major provocation existing in rural enterprises today refers to the training of successors, as they need to develop skills for agricultural practices and knowledge of agribusiness management (Burton \& Fischer, 2015; Morais et al., 2017).

The information extracted with the characterization of clusters contribute to the formation and reflection on the policies for the use and management of land currently in force in Brazil, once it enables to understand the dynamics of the regional development of municipalities where sugarcane is currently under implementation or expansion stages. In Goiás, the production system related to Sugarcane APLs has advanced in comparison to other agroindustry complexes, increasing the production competition in grains, cattle farming and savanna areas (Abdala \& Riberio, 2011), in especial the Goiás Southwest, where the APL in Quirinópolis is located, became one of the main Brazilian agricultural areas, structured in the creation of major agroindustry complexes, creating APLs for agricultural production that cover since the production of raw-material, processing and logistics, until delivery to the consumer market, and has as one of the decision points the choice of the type of contract and its consequences (Abdala \& Ribeiro, 2011; Pereira Trindade, 2018). In this environment, logistics matters are important as those demonstrated in the characterization of Cluster 1 and 2, due to the intense growth and competition to establish the most suitable infrastructure with reduced costs (Strelecek et al., 2011).

Recent studies have demonstrated the advance of the sugarcane production system in areas that cause the conversion to agriculture, pasture and remaining of vegetation in the search for better soil and greatly in smaller farms, as those characterized in Cluster 2 (Castro et al., 2010; Gilio \& Moraes, 2016; Spera et al., 2017). Thus, it is doubtful to perform the official conception of the policies for the use of land, with the inclusion of biofuel to the Agroenergy National Plan (PNA), for sugarcane to advance over pasture areas, mainly degraded areas, preserving food producing land and the Savanna area (Sauer \& Pietrafesa, 2012).

Even considering the PNA, which aims to alter the use of land primarily on degraded pasture, the advance of the sugarcane culture and respective APL is noticeable, in a continuous manner over lands with agriculture, in this case with the production of grains, contradicting the agroenergy public policies, confirming the contribution that the analysis of sugarcane clusters can bring (Barbalho et al., 2013). The effects of the expansion caused by the Sugarcane APL production system are so expressive, that allow to conclude that in the Southwest Goiás such are in disagreement with the environmental directives of the Agroenergy National Plan (Pereira Trindade, 2018). This research was performed directly with an agent of the production chain, supplier of raw-materials, allowing for in-depth knowledge of its necessities and challenges, and consequently, an interference factor in the creation and update of land use policies.

But the data also contribute directly in the construction of the rural planning for rural establishments in a stricto sensu manner, once it allows to discuss the best conditions for the establishment of logistics, cost formation, capacitation of successors, dimensioning of the productive area and respective effects in the rural exodus. Johansen $\&$ Chandler (2015), suggest that the literature on rural planning may direct the focus of power assessment, instead of those who have power, rather to those that don't have, which participation shall the successors have in this process, once such require a more specific preparation, once the results per cluster were not satisfactory (Cluster 1 with 2.81 points and Cluster 2 with 2.22). But the role of planning within a regional development perspective shall consider the APL Stakeholders, role that the rural enterprise assumes in a very relevant manner for the success of several agents (Kerselaers et at., 2013). These observations contribute to the creation of sectoral policies for the use of land and regional economic development, as imply in a theoretical consolidation of precepts on the expansion of sugarcane, as also imply under the perspective of rural practice in elements for the improvement of planning of the agricultural enterprise within the perspective of regional development.

It is concluded that through cluster analysis that the type of contract variable and the size of the establishment are the most significant factors that influence the rural exodus index and the composition of operating costs in the sugarcane LPA in Quirinópolis. 


\section{Acknowledgements}

This research was supported by the Goiás Sugarcane Suppliers Association (APROCANA - Associação dos Fornecedores de Cana Goiás), Departments of Agriculture and Environment, Industry and Commerce and Tourism of the Quirinópolis City Hall, Faculdade Quirinópolis and led by the Graduate Program in Agricultural Sciences of the Goiano Federal Institute (IF GOIANO - Instituto Federal Goiano), Campus Rio Verde. We especially thank the institutional support of the Goiano Federal Institute (IF GOIANO), Campus Rio Verde. The opinions expressed in this article do not necessarily reflect the opinions of our supporters or partners.

\section{References}

Abdala, K. O., Ribeiro, F. L. (2011). Análise dos impactos da competição pelo uso do solo no estado de Goiás durante o período 2000 a 2009 provenientes da expansão do complexo sucroalcooleiro. Revista Brasileira de Economia, Rio de Janeiro, 65(4), 373-400.

Assunção, J., Pietracci, B., \& Souza, P. (2016). Fueling development: sugarcane expansion impacts in Brazil. $\begin{array}{lllll}\text { Climate Policy } & \text { Initiative. } & \text { Retrieved } & \text { Sept. } & \text { 2016, }\end{array}$ https://climatepolicyinitiative.org/publication/sugarcanes-role-fueling-economy/

Barbalho, M. G. S., Silva, A. A., \& Castro, S. S. (2013). A expansão da área de cultivo da cana-de-açúcar na região sul do estado de Goiás de 2001 a 2011. Revista Brasileira de Ciências Ambientais, Rio de Janeiro, 29, 98-110.

Burton, R. J. F., \& Fischer, H. (2015). European Society for Rural Sociology. Sociologia Ruralis, 55(2). https://doi.org.10.1111/soru.12080

Castro, S. S. et al. (2010). A Expansão da Cana-de-açúcar no Cerrado e no Estado de Goiás: elementos para uma análise espacial do processo. Boletim Goiano de Geografia, Goiânia, 30(1), 171-191.

Creswell, J. W. (2017). Research Design: Qualitative, Quantitative, and Mixed Methods Approaches. SAGE Publicat.

De Sordi, J. O., \& Meireles, M. (2012). Arranjo produtivo local ou aglomerado de empresas? Distinção por atributos associados à temática transferência de informação. Revista de Administração Pública, 46(3). https://doi.org/10.1590/S0034-76122012000300008

Duarte, C. G., Gaudreau, K., Gibson, R. B., \& Malheiros, T. F. (2013). Sustainability assessment of sugarcane-ethanol production in Brazil: A case study of a sugarcane mill in São Paulo state. Ecological Indicators, 30, 119-129. https://doi.org/10.1016/j.ecolind.2013.02.011

Egeskog, A., Barretto, A., Berndes, G., Sparovek, G., Freitas, F., Holmén, M., \& Torén, J. (2016). Actions and opinions of Brazilian farmers who shift to sugarcane-an interview-based assessment with discussion of implications for land-use change. Land Use Policy, 57, 594-604. https://doi.org/10.1016/j.landusepol.2016.06.022

Escobal, J., Favareto, A., Aguirre, F., \& Ponce, C. (2015). Linkage to dynamic markets and rural territorial development in Latin America. Word Development, 73, 44-55. https://doi.org/10.1016/j.worlddev.2014.09.017

Franks, J. R. (2014). Sustainable intensification: A UK perspective. Food Policy, 47, 71-80. https://doi.org/10.1016/j.foodpol.2014.04.007

Garrett, R. D., Lambin, E. F., \& Naylor, R. L. (2013). The new economic geography of land use change: supply chain configurations and land use in the Brazilian Amazon. Land Use Policy, 34, 265-275. https://doi.org/10.1016/j.landusepol.2013.03.011

Gilio, L., \& Moraes, M. A. F. D. (2016). Sugarcane industry's socioeconomic impact in São Paulo, Brazil: a spatial dynamic panel approach. Energy Economic, 58, 27-37. https://doi.org/10.1016/j.eneco.2016.06.005

Guanziroli, C., Buainain, A., \& Sabbato, A. (2013). Family farming in Brazil: Evolution between the 1996 and 2006 agricultural censuses. Journal Peasant Studies, 40(50), 817-843. https://doi.org/10.1080/03066150.2013.857179

IBGE - Instituto Brasileiro de Geografia e Estatística. (2018a). Censo Agropecuário - Resultados preliminares, 2017. Retrieved 30 Sept. 2018, from https://sidra.ibge.gov.br/

IBGE - Instituto Brasileiro de Geografia e Estatística. (2018b). Cidades. Retrieved 30 Jan. 2018, from http://cidades.ibge.gov.br/xtras/home.php

Johansen, P. H., \& Chandler, T. L. (2015). Mechanisms of power in participatory rural planning. Journal of Rural Studies, 40, 12-20. http:// doi.org/10.1016/j.jrurstud.2015.05.006 0743-0167/ 
Justen, G. S., \& Paes-de-Souza, M. (2017). Social Affairs and Definition of Territory: study in Local Productive Arrangement (APL) of Brazil-Nuts in Acre State. Revista de Ciências da Administração. 19(47), 114-130. https://doi.org/10.5007/2175-8077.2017v19n47p114

Kerselaers, E., Roggea, E., Vanemptenb, E., Lauwers, L., \& Huylenbroeck, G. V. (2013). Changing land use in the countryside: Stakeholders' perception of the ongoing rural planning processes in Flanders. Land Use Policy, 32, 197-206. http://doi.org/10.1016/j.landusepol.2012.10.016

Maia, C., Fideles, J., \& Medina, G. (2016). Reforma agrária. In G. Medina (Ed.), Agricultura familiar em Goias: Lições para o Assessoramento Técnico. Goiânia: Editora da UFG.

Mangoyana, R. B., Smith, T. F., \& Simpson, R. A. (2013). Systems approach to evaluating sustainability of biofuel systems. Renewable \& Sustainable Energy Reviews, 25, 371-380. https://doi.org/10.1016/j.rser.2013.05.003

Medina, G., \& Santos, A. P. (2017). Curbing enthusiasm for Brazilian agribusiness: The use of actor-specific assessments to transform sustainable development on the ground. Applied Geography, 85, 101-112. https://doi.org/10.1016/j.apgeog.2017.06.003

Medina, G., Almeida, C., Novaes, E., Godar, J., \& Pokorny, B. (2015). Development conditions for family farming: lessons from Brazil. World Development, 74, 386-396. http://dx.doi.org/10.1016/j.worlddev.2015.05. 023

Morais, M., Binotto, E., \& Borges, J. A. R. (2017). Identifying beliefs underlying successors' intention to take over the farm. Land Use Policy, 68, 48-58. http://dx.doi.org/10.1016/j.landusepol.2017.07.024

Nacife, J. M., Soares, F. A. L., \& Castoldi, G. (2019). Socioeconomic Characteristics and the Impacts of Land Use Changes to Sugar Cane in Quirinópolis, Brazil. Journal of Agricultural Science, 11(10), 180-193. https://doi.org/10.5539/jas.v11n10p180

Nagavarapu, S. (2010). Implications of unleashing Brazilian ethanol: trading off renewable fueld for how much forest and savanna land. Working Paper.

Pereira Trindade, S., Faria, K., \& Simões de Castro, S. (2018). Análise da expansão canavieira e as mudanças de uso do solo no sudoeste goiano de 1985 a 2016. Boletim Goiano de Geografia, 38(3), 569-590. https://doi.org/10.5216/bgg.v38i3.56359

Pervaiz, B. Li. N., Manzoor, M. Q., \& Yaseen, M. (2017). Socio-Economic Characteristics of Farming Community and Food Security Situation in Punjab, Pakistan. Journal of Agricultural Science, 9(8), 130-142. https://doi.org/10.5539/jas.v9n8p130

Petrini, M. A., Rocha, J. V., \& Brown, J. C. (2017). Mismatches between mill-cultivated sugarcane and smallholding farming in Brazil: Environmental and socioeconomic impacts. Journal of Rural Studies, 50(2), 218-227. https://doi.org/10.1016/j.jrurstud.2017.01.009

Ribeiro, B. E. (2013). Beyond commonplace biofuels: Social aspects of ethanol. Energy Policy, 57, 355-362. https://doi.org/10.1016/j.enpol.2013.02.004

Ribeiro, K. A., Nascimento, D. C., Cassunde, Junior, N. F., \& Morato, J. A. Q. (2013). Environmental costs: an exploratory study in a shipyard in Southern Brazil. Revista de Gestão, Finanças e Contabilidade, UNEB, Salvador, 3(2), 99-120. https://doi.org/10.1016/j.enpol.2013.02.004

Roviero, A. (2014). Estudo dos pequenos produtores e fornecedores de cana e terra para as usinas de açúcar e álcool do interior paulista: o caso da região central do Estado de São Paulo. REDD - Revista Espaço de Diálogo e Desconexão, Araraquara, 8(1), 2.

Santos, G. E. O. (2016). Cálculo amostral: calculadora online. Retrieved June 30, 2016, from http://www.calculoamostral.vai.la

Sauer, S., \& Pietrafesa, J. P. (2012). Cana-de-açúcar, financiamento, público e produção de alimentos no Cerrado. Campo-Território: Revista de Geografia Agrária, Uberlândia, 7(14), 1-29.

Spera, S., Van, Wey, L., \& Mustard, J. (2017). The drivers of sugarcane expansion in Goiás, Brazil. Land Use Policy, 66(7), 111-119.

Strelecek, F., Zdenek, R., \& Lososová, J. (2011) Influence of the production change on the return to scale. Agricultural Economics, Prague, 57(4), 159-168.

Trindade, S. P. (2015). Agricultural aptitude, changes in land use, conflicts and direct and indirect impacts of sugarcane expansion in the southwestern region of Goiás (187f, Tese Doctorate degree in Environmental Sciences, Universidade Federal de Goiás, Goiânia). 